\title{
Learning Style Preferences of Prospective Teachers of Physical Education and Sport
}

\author{
Özgür Bostanci
}

Yasar Dogu Sports Sciences Faculty, Ondokuz Mayls University, Samsun, Turkey. Email:bostanci@omu.edu.tr

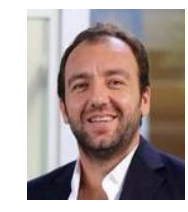

\begin{abstract}
The aim of this study is to find out the VARK learning styles of students receiving sport sciences education and to investigate their relationship with different variables. 169 undergraduate students studying at Ondokuz Mayıs University Yaşar Doğu Sport Sciences Faculty participated in this cross-sectional study voluntarily. VARK learning style questionnaire, which was developed by Fleeming (2009) and which was adapted into Turkish by Kalkan (2008) was used to find out learning preferences. In data analysis, descriptive statistics and Chi-square test were used. According to the average scores obtained, it was found that the students preferred kinesthetic learning style the most $(7.08 \pm 2.74)$. In addition, it was found that $142(84 \%)$ students preferred unimodality learning model, while $27(16 \%)$ students preferred multimodality learning model. When learning style model preferences were analyzed according to all variables, no statistically significant difference was found ( $p>0.05$ ); however, it was found that multimodality learning style was preferred more intensely in all variables. As a result, it was found that dominant learning style of the faculty of sport sciences students was kinesthetic learning style and that multimodality learning style was preferred more in all variables. It is thought that the emergence of this result is due to students' sport background and their applied lessons. It is predicted that as a result of determining the learning styles of sport sciences students and conducting studies related to these, academic quality and achievement can be increased.
\end{abstract}

Keywords: Learning styles, VARK, Physical education, Sport, Dominant learning style, students.

Citation | Özgür Bostanci (2020). Learning Style Preferences of Prospective Teachers of Physical Education and Sport. Asian Journal of Education and Training, 6(2): 231-236.

History:

Received: 10 January 2020

Revised: 25 February 2020

Accepted: 27 March 2020

Published: 14 April 2020

Licensed: This work is licensed under a Creative Commons

Attribution 3.0 License $(\mathrm{cc}) \mathbf{E}$

Publisher: Asian Online Journal Publishing Group
Funding: This study received no specific financial support.

Competing Interests: The author declares that there are no conflicts of interests regarding the publication of this paper.

Transparency: The author confirms that the manuscript is an honest, accurate, and transparent account of the study was reported; that no vital features of the study have been omitted; and that any discrepancies from the study as planned have been explained.

Ethical: This study follows all ethical practices during writing.

\section{Contents}

1. Introduction 


\section{Contribution of this paper to the literature}

The aim of this study is to find out the VARK learning styles of students receiving sport sciences education.

\section{Introduction}

Updates in educational subjects with the developing technology becoming an important part of daily life have caused individual differences in terms of students' absorbing and using knowledge (Cavusoglu, Yılmaz, Kabadayı, Abacı, \& Tasmektepligıl, 2017; Weng, Ho, Yang, \& Weng, 2018). Accordingly, for a quality education, learning and teaching processes should be monitored, how students learn information should be clarified and individual differences should be taken into consideration (Miyake \& Friedman, 2012).

The process of education can be successful only when we are sensitive to these individual differences. Students' success will increase when teaching activities are planned by taking individual differences into consideration because thinking that all students have similar characteristics prevents their ability and success from appearing (Doğan, Yılmaz, Kabadayı, \& Mayda, 2018; Karataş, Sır, \& Celiköz, 2015). The fact that each student has subjective thoughts and different experiences shows that their learning process is also different. For this reason, each individual has a specific learning style in the education process (Bilgin \& Bahar, 2008). Learning styles that are customized for each individual are defined in different ways in literature. While Kolb defined learning styles as a personally preferred process in absorbing and using knowledge(Kolb, 1984) Dunn evaluated learning style as a situation that occurs in different environments as opposed to mental and intellectual processes (Dunn \& Dunn, 1993). Gregorc defined learning styles as subjective and observable behaviours which give information about students' abilities, their thoughts about the world and how they learn (Gregorc, 1979). Riding and Rayner stated that learning styles were individuals' unchanging or slightly changing characteristics (Riding \& Rayner, 2013).

When studies conducted on learning styles are examined (Dunn \& Dunn, 1992; Fleming, 2001; Kırmacı et al., 2019; Leite, Svinicki, \& Shi, 2010) it can be seen that learning style preferences are different. While some individuals prefer to use a single learning style, others prefer to use more than one learning style because these preferences contribute to creating a more effective learning environment. In the light of this information, it is a matter of curiosity which styles sport sciences students, who have intense applied lessons, use.

Significance of the study; the study will examine the learning styles of sport sciences faculty students and contribute to more effective implementation of education programs and shaping education programs according to the interests and abilities of students. The aim of this study, which will make a significant contribution to literature, is to find out the learning styles of sport sciences faculty students and to examine how some variables affect their learning styles.

\section{Material and Method}

\subsection{Sample and Procedure}

The population of the study consists of undergraduate students of Sport Sciences Faculty, while the sample group consists of 169 undergraduate students studying at Ondokuz Mayıs University Yaşar Doğu Faculty of Sport Sciences during the Academic Year 2018-2019 Table 1. Random sampling method was used in this cross-sectional study and the participants were chosen on a voluntary basis. The data were then collected, entered into the computer,and collated. Each student's results were calculated to identify their learning style preference.

Table-1. Descriptive data and VARK learning style models.

\begin{tabular}{|c|c|c|c|}
\hline Variables & Group & $f$ & $\%$ \\
\hline \multirow{2}{*}{ Gender } & Male & 119 & 70.40 \\
\hline & Female & 50 & 29.60 \\
\hline \multirow{3}{*}{ Age } & $19-20$ & 47 & 27.80 \\
\hline & $21-22$ & 70 & 41.40 \\
\hline & 23 and older & 52 & 30.80 \\
\hline \multirow{3}{*}{ State of doing sport } & Active-Licensed & 53 & 31.40 \\
\hline & Previously licensed & 99 & 58.60 \\
\hline & No license & 17 & 10.10 \\
\hline \multirow{6}{*}{ Monthly level of income } & $\mathrm{O}-1000 \mathrm{TL}$ & 12 & 7.10 \\
\hline & $1001-1500 \mathrm{TL}$ & 49 & 29.00 \\
\hline & $1501-2000 \mathrm{TL}$ & 46 & 27.20 \\
\hline & $2001-2500 \mathrm{TL}$ & 19 & 11.20 \\
\hline & $2501-3000 \mathrm{TL}$ & 19 & 11.20 \\
\hline & 3000 TL and more & 24 & 14.20 \\
\hline \multirow{3}{*}{ Place of residence } & Provincial centre & 95 & 56.20 \\
\hline & Town centre & 55 & 32.50 \\
\hline & Village & 19 & 11.20 \\
\hline \multirow{4}{*}{ VARK } & Unimodal Learning & 51 & 30.20 \\
\hline & Bi-modal Learning & 23 & 13.60 \\
\hline & Tri-modal Learning & 23 & 13.60 \\
\hline & Quad-modal Learning & 72 & 42.60 \\
\hline Total & & 169 & 100 \\
\hline
\end{tabular}

Note: f: Frequency, \%: Percentage.

\subsection{VARK Learning Style Version 7.1}

VARK learning style questionnaire, which was developed by Fleming (Fleeming, 2009) and which was adapted into Turkish by Kalkan (2008) was used to find out learning preferences. VARK questionnaire, which consists of 16 questions, seeks answers to what students can do by creating different scenarios. The questionnaire in which more 
than one option can be chosen consists of visual, aural, read/write and kinesthetic sensory categories. The participants can choose more than one learning style and this result shows that the participant is more prone to multiple learning styles. To determine the percentage of students for each VARK modality and for all possible combinations of modalities, the number of students who preferred each learning style modality was divided by the total number of students.

\subsection{Data Analysis}

The sample size calculation showed that to have 5\% error and a 90\% confidence level the total sample size would need to be at least 150 students. The SPSS 22.0 (SPSS Inc., Chicago, IL, USA) version was used for statistical analyses. The data were expressed in terms of mean, standard deviation, minimum, maximum, percentage, and frequency. The Kolmogorov-Smirnov test was used to check normality of the data. Chi-Square was used in group comparisons of qualitative data. Significance was defined as $\mathrm{p} \leq 0.05$.

\section{Results}

Descriptive data and VARK learning style models distribution of the subjects are given in Table 1 above.

\begin{tabular}{l|c|c|c|c}
\multicolumn{5}{c}{ Table-2. Mean scores of the sub-dimensions of VARK learning style questionnaire. } \\
\hline VARK & Min. & Max. & Mean & S.D. \\
\hline Visual & 0.00 & 15.00 & 4.10 & 2.71 \\
\hline Aural & 1.00 & 16.00 & 6.44 & 2.76 \\
\hline Read-write & 0.00 & 14.00 & 4.89 & 2.48 \\
\hline Kinesthetic & 1.00 & 15.00 & 7.08 & 2.74 \\
\hline Note: Min: Minimum Max: Maximum S.D: Standart Deviation.
\end{tabular}

When the average scores were examined, it was found that the learning style most preferred by the students was kinesthetic $(7.08 \pm 2.74)$ Table 2 .

Table-3. Percentage and frequency distribution of dominant learning styles.

\begin{tabular}{|c|c|c|c|}
\hline \multicolumn{2}{|c|}{ Learning styles } & f & $\%$ \\
\hline \multirow{4}{*}{ Uni-modal } & Visual (V) & 4 & 2.40 \\
\hline & Aural (A) & 45 & 26.60 \\
\hline & Read/Write (R/W) & 19 & 11.20 \\
\hline & Kinesthetic $(\mathrm{K})$ & 74 & 43.80 \\
\hline & & 142 & $\% 84$ \\
\hline \multirow{9}{*}{ Multi-modal } & Bi-Modal Learning Styles & 26 & 15.50 \\
\hline & Aural-Kinesthetic (AK) & 11 & 6.50 \\
\hline & Aural- Read/Write (AR) & 3 & 1.80 \\
\hline & Read/Write - Kinesthetic (RK) & 5 & 3.00 \\
\hline & Visual - Aural (VA) & 5 & 3.00 \\
\hline & Visual - Kinesthetic (VK) & 2 & 1.20 \\
\hline & Quad-Modal Learning Styles & 1 & 0.60 \\
\hline & Visual - Aural - Kinesthetic - Read/Write (VARK) & 1 & 0.60 \\
\hline & & 27 & $\% 16$ \\
\hline Total & & 169 & 100 \\
\hline
\end{tabular}

Note: f: Frequency \%: Percentage.

When the results of learning styles were examined, it was found that $142(84 \%)$ of the students used unimodality learning style, while $27(16 \%)$ used multimodality learning style Table 3.

\begin{tabular}{|c|c|c|c|c|}
\hline Variables & Male & Female & Total & \\
\hline Unimodal & 32 & 19 & 51 & \multirow{15}{*}{ 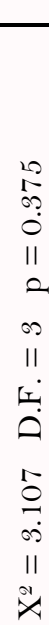 } \\
\hline Learning style \% & 62.7 & 37.3 & 100.0 & \\
\hline Gender \% & 26.9 & 38.0 & 30.2 & \\
\hline Bi-modal & 17 & 6 & 23 & \\
\hline Learning style \% & 73.9 & 26.1 & 100.0 & \\
\hline Gender \% & 14.3 & 12.0 & 13.6 & \\
\hline Tri-modal & 15 & 8 & 23 & \\
\hline Learning style \% & 65.2 & 34.8 & 100.0 & \\
\hline Gender \% & 12.6 & 16.0 & 13.6 & \\
\hline Quad-Modal & 55 & 17 & 72 & \\
\hline Learning style \% & 76.4 & 23.6 & 100.0 & \\
\hline Gender \% & 46.2 & 34.0 & 42.6 & \\
\hline Total & 119 & 50 & 169 & \\
\hline Learning style \% & 70.4 & 29.6 & 100.0 & \\
\hline Gender \% & 100.0 & 100.0 & 100.0 & \\
\hline
\end{tabular}

Note: $\mathrm{X}^{2}$ : Chi-Square D.F: degrees of freedom $\mathrm{p}>0.05$.

When the gender variable was examined, no significant difference was found between the preferences of the participants $(\mathrm{p}>0.05)$. When the distributions were examined, it was found that while male students were mostly inclined to ML style, female students were mostly inclined to SL style Table 4. 
Table-5. Analysis of VARK learning style model preferences in terms of age.

\begin{tabular}{|c|c|c|c|c|c|}
\hline Variables & 19-20 Years of age & 21-22 Years of age & 23 and older & Total & \\
\hline Unimodal & 15 & 20 & 16 & 51 & \multirow{7}{*}{$\begin{array}{l}\exists \\
\sigma \\
0 \\
11 \\
0\end{array}$} \\
\hline Learning style \% & 29.4 & 39.2 & 31.4 & 100.0 & \\
\hline Age \% & 31.9 & 28.6 & 30.8 & 30.2 & \\
\hline Bi-modal & 4 & 12 & 7 & 23 & \\
\hline Learning style \% & 17.4 & 52.2 & 30.4 & 100.0 & \\
\hline Age $\%$ & 8.5 & 17.1 & 13.5 & 13.6 & \\
\hline Tri-modal & 7 & 10 & 6 & 23 & \\
\hline Learning style \% & 30.4 & 43.5 & 26.1 & 100.0 & \multirow{4}{*}{$\begin{array}{l}0 \\
11 \\
.\end{array}$} \\
\hline Age \% & 14.9 & 14.3 & 11.5 & 13.6 & \\
\hline Quad-Modal & 21 & 28 & 23 & 72 & \\
\hline Learning style \% & 29.2 & 38.9 & 31.9 & 100.0 & \\
\hline Age \% & 44.7 & 40.0 & 44.2 & 42.6 & \multirow{4}{*}{$\begin{array}{l}0 \\
\infty \\
0 \\
0 \\
0 \\
11 \\
0 \\
0\end{array}$} \\
\hline Total & 47 & 70 & 52 & 169 & \\
\hline Learning style \% & 27.8 & 41.4 & 30.8 & 100.0 & \\
\hline Age \% & 100.0 & 100.0 & 100.0 & 100.0 & \\
\hline
\end{tabular}

Note: $\mathbf{X}^{2}$ : Chi-Square D.F: degrees of freedom $\mathrm{p}>0.05$

No difference was found as a result of the analysis conducted in terms of age groups ( $>>0.05)$. However, ML was more preferred in all age groups and the highest distribution was found in the 21-22 age group Table 5.

Table-6. Analysis of VARK Learning Style Model preferences in terms of the state of doing sport.

\begin{tabular}{|c|c|c|c|c|c|}
\hline Variables & Active licensed & Previously licensed & No Licence & Total & \multirow{16}{*}{$\begin{array}{c}5 \\
0 \\
0 \\
11 \\
0 \\
0 \\
11 \\
0 \\
0 \\
0 \\
0 \\
0 \\
0 \\
0 \\
11 \\
0 \\
0 \\
0\end{array}$} \\
\hline Unimodal & 20 & 25 & 6 & 51 & \\
\hline Learning style \% & 39.2 & 49.0 & 11.8 & 100.0 & \\
\hline Sport \% & 37.7 & 25.3 & 35.3 & 30.2 & \\
\hline Bi-modal & 5 & 18 & $\mathrm{O}$ & 23 & \\
\hline Learning style \% & 21.7 & 78.3 & 0.0 & 100.0 & \\
\hline Sport \% & 9.4 & 18.2 & 0.0 & 13.6 & \\
\hline Tri-modal & 3 & 17 & 3 & 23 & \\
\hline Learning style \% & 13.0 & 73.9 & 13.0 & 100.0 & \\
\hline Sport \% & 5.7 & 17.2 & 17.6 & 13.6 & \\
\hline Quad-Modal & 25 & 39 & 8 & 72 & \\
\hline Learning style \% & 34.7 & 54.2 & 11.1 & 100.0 & \\
\hline Sport \% & 47.2 & 39.4 & 47.1 & 42.6 & \\
\hline Total & 53 & 99 & 17 & 169 & \\
\hline Learning style \% & 31.4 & 58.6 & 10.1 & 100.0 & \\
\hline Sport \% & 100.0 & 100.0 & 100.0 & 100.0 & \\
\hline
\end{tabular}

Note: $\mathbf{X}^{2}$ : Chi-Square D.F: degrees of freedom p $>0.05$.

Although there were no statistical differences in the results in terms of the state of doing sport ( $p>0.05)$, it was found that there were more students who were previously licensed and that they used ML. In addition, it was found that none of the students with no license used two learning styles Table 6.

\begin{tabular}{|c|c|c|c|c|c|c|c|c|}
\hline Variables & $\begin{array}{l}\text { Less } \\
1000\end{array}$ & $1001-1500$ & $\begin{array}{l}1501- \\
2000\end{array}$ & $\begin{array}{l}2001- \\
2500\end{array}$ & $\begin{array}{l}2501- \\
3000\end{array}$ & $\begin{array}{l}3000 \text { and } \\
\text { more }\end{array}$ & Total & \\
\hline Unimodal & 3 & 12 & 12 & 6 & 7 & 11 & 51 & \multirow{6}{*}{$\begin{array}{l}\text { I } \\
1 \\
0 \\
11 \\
2\end{array}$} \\
\hline Learning style \% & 5.9 & 23.5 & 23.5 & 11.8 & 13.7 & 21.6 & 100.0 & \\
\hline Income (TL) \% & 25.0 & 24.5 & 26.1 & 31.6 & 36.8 & 45.8 & 30.2 & \\
\hline Bi-modal & 1 & 8 & 7 & 4 & 2 & 1 & 23 & \\
\hline Learning style \% & 4.3 & 34.8 & 30.4 & 17.4 & 8.7 & 4.3 & 100.0 & \\
\hline Income (TL) \% & 8.3 & 16.3 & 15.2 & 21.1 & 10.5 & 4.2 & 13.6 & \\
\hline Tri-modal & 1 & 8 & 7 & 2 & 4 & 1 & 23 & 20 \\
\hline Learning style \% & 4.3 & 34.8 & 30.4 & 8.7 & 17.4 & 4.3 & 100.0 & $\overline{\|}$ \\
\hline Income (TL) \% & 8.3 & 16.3 & 15.2 & 10.5 & 21.1 & 4.2 & 13.6 & i. \\
\hline Quad-Modal & 7 & 21 & 20 & 7 & 6 & 11 & 72 & $\dot{a}$ \\
\hline Learning style \% & 9.7 & 29.2 & 27.8 & 9.7 & 8.3 & 15.3 & 100.0 & $r$ \\
\hline Income (TL) \% & 58.3 & 42.9 & 43.5 & 36.8 & 31.6 & 45.8 & 42.6 & in \\
\hline Total & 12 & 49 & 46 & 19 & 19 & 24 & 169 & $\stackrel{0}{-}$ \\
\hline Learning style \% & 7.1 & 29.0 & 27.2 & 11.2 & 11.2 & 14.2 & 100.0 & 11 \\
\hline Income (TL) \% & 100.0 & 100.0 & 100.0 & 100.0 & 100.0 & 100.0 & 100.0 & $\sqrt{x}$ \\
\hline
\end{tabular}

Note: TL: Turkish Lira $\mathrm{X}^{\text {: }}$ Chi-Square D.F: degrees of freedom $\mathrm{p}>0.05$.

Learning styles distributions are similar in terms of the levels of monthly income ( $p>0.05)$. While 1500 TL is the group with the highest distribution, ML is the most preferred learning style Table 7. 
Table-8. Analysis of VARK Learning Style Model preferences in terms of place of residence.

\begin{tabular}{|c|c|c|c|c|c|}
\hline Variables & Provincial centre & Town centre & Village & Total & \\
\hline Unimodal & 31 & 16 & 4 & 51 & \multirow{7}{*}{ 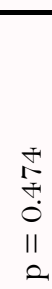 } \\
\hline Learning style \% & 60.8 & 31.4 & 7.8 & 100.0 & \\
\hline Place of residence \% & 32.6 & 29.1 & 21.1 & 30.2 & \\
\hline Bi-modal & 12 & 6 & 5 & 23 & \\
\hline Learning style \% & 52.2 & 26.1 & 21.7 & 100.0 & \\
\hline Place of residence \% & 12.6 & 10.9 & 26.3 & 13.6 & \\
\hline Tri-modal & 13 & 6 & 4 & 23 & \\
\hline Learning style \% & 56.5 & 26.1 & 17.4 & 100.0 & \multirow{4}{*}{$\begin{array}{l}0 \\
11 \\
0\end{array}$} \\
\hline Place of residence \% & 13.7 & 10.9 & 21.1 & 13.6 & \\
\hline Quad-Modal & 39 & 27 & 6 & 72 & \\
\hline Learning style \% & 54.2 & 37.5 & 8.3 & 100.0 & \\
\hline Place of residence \% & 41.1 & 49.1 & 31.6 & 42.6 & $\begin{array}{l}\infty \\
10 \\
10\end{array}$ \\
\hline Total & 95 & 55 & 19 & 169 & ספ \\
\hline Learning style \% & 56.2 & 32.5 & 11.2 & 100.0 & 11 \\
\hline Place of residence \% & 100.0 & 100.0 & 100.0 & 100.0 & $\ddot{x}$ \\
\hline
\end{tabular}

No significant difference was found in learning styles analysis of the participants in terms of place of residence $(\mathrm{p}>0.05)$. It was found that the participants who lived in provincial centres, which had the highest number of participants, were inclined to ML the most Table 8.

\section{Discussion and Conclusion}

The present study investigated the learning styles of sport sciences faculty students determined with a random sampling method and examined whether the variables of gender, age, state of doing state, level of monthly income and place of residence caused a significant difference in learning styles. Three main results were found: a) According to the results, kinesthetic learning is the most dominant learning style of sport sciences students. b) Few sport sciences students use visual learning. c) In all variables, multiple learning style was proffered more. These results are important for the literature.

Although a great number of studies have been conducted about learning styles in different areas (Fleming, 2001; Katsioloudis \& Fantz, 2012; Leite et al., 2010) limited number of studies have been conducted about sport sciences students (Braakhuis, Williams, Fusco, Hueglin, \& Popple, 2015; Türker, 2017). In addition, the present study is the first one on sport sciences students which included the variables of monthly level of income and place of residence.

When the average scores of the sub-dimensions of VARK learning styles questionnaire were examined, it was found that kinesthetic was the most preferred learning style (7.08 \pm 2.74$)$, while visual was the least preferred

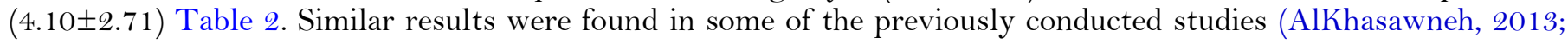
Braakhuis et al., 2015; Türker, 2017). Although learning styles differed in terms of the faculties the students were studying in, their dominant learning styles were found to be aural and kinesthetic learning styles in general (Cetin \& Erel, 2018; Powers, 2016; Wong, Siow, Kumarasamy, \& Suhaimi, 2017).

According to the percentage and frequency distributions of dominant learning styles, few students in the study $(\mathrm{f}=4,2,40 \%)$ were found to prefer visual learning style. In addition, $142(84 \%)$ of the students stated that they used unimodality learning style, while $27(16 \%)$ stated that they used multimodality learning style Table 3 . In a study conducted on sport sciences faculty students in 2017, Türker (2017) found that 664 (81\%) of the participants used unimodality learning style, while $156(19 \%)$ used multimodality learning style.

No significant difference was found between the preferences of the participants in terms of the variable of gender ( $p>0.05)$. In some of the studies conducted, the variable of gender was found to cause a significant difference on learning styles (Braakhuis et al., 2015; Park, Nielsen, \& Woodruff, 2014) while in others it was not found to cause a significant difference (Dobson, 2010; Güneş \& Erkan, 2017). No difference was found between the results of age groups $(\mathrm{p}>0.05)$. The most frequently preferred learning styles were ML and SL. Similar results were found in Baykan and Naçar's study (Baykan \& Naçar, 2004).

No statistically significant difference was found when the results of the state of doing sport were examined ( $>$ 0.05). In their study on elite team athletes, Braakhuis et al. (2015) also found similar results. It is thought that the state of having license did not affect the results since the students of the faculty of sport sciences are engaged in sport all the time.

Learning style preferences were found to be similar in terms of the level of monthly income and place of residence $(p>0.05)$. In both variables, ML was the most preferred learning style. The highest numbers of students were within the 1001-1500 TL income level group. The highest number of students lived in provincial centre in terms of place of residence. No studies have been conducted on sport sciences students with these two variables; thus, it is thought that the study will make significant contribution to national and international literature.

As a conclusion, although sport sciences students had kinesthetic learning style as the dominant learning style, they also have the characteristics of the other learning preferences since they are intertwined with sports. The result that multiple learning style was preferred more in all variables can be explained with this. In addition, it is thought that knowing about the learning styles of sport sciences students will be an important resource for sport educators in increasing quality. It is recommended that similar studies should be conducted on academic achievement and learning styles of undergraduate students and graduate students. In addition, it is predicted that academic achievement can be increased through more quality education by monitoring the learning styles of students starting from their first year. 


\section{References}

AlKhasawneh, E. (2013). Using VARK to assess changes in learning preferences of nursing students at a public university in Jordan: Implications for teaching. Nurse Education Today, 33(12), 1546-1549.Available at: https://doi.org/10.1016/j.nedt.2012.12.017.

Baykan, Z., \& Naçar, M. (2004). Learning styles of first-year medical students attending Erciyes University in Kayseri, Turkey. Advances in Physiology Education, 31(2), 158-160.

Bilgin, İ., \& Bahar, M. (2008). Investigation of the relationship between teaching and learning styles of primary school teachers. Gazi University Journal of the Gazi Faculty of Education, 28(1), 19-38.

Braakhuis, A., Williams, T., Fusco, E., Hueglin, S., \& Popple, A. (2015). A comparison between learning style preferences, gender, sport and achievement in elite team sport athletes. Sports, 3(4), 325-334.Available at: https://doi.org/10.3390/sports3040325.

Cavusoglu, G., Yılmaz, A., Kabadayı, M., Abacı, S., \& Tasmektepligıl, M. (2017). Comparison of narcissism levels of students in the Faculty of Sports Sciences in terms of some demographic variables. Turkish Journal of Sport and Exercise, 19(2), 150-156.Available at: https://doi.org/10.15314/tsed.296702.

Cetin, S. Y., \& Erel, S. (2018). Determining the learning preferences of the students of the faculty of health sciences in Cyprus International University. Paper presented at the SHS Web of Conferences.

Dobson, J. L. (2010). A comparison between learning style preferences and sex, status, and course performance. Advances in Physiology Education, 34(4), 197-204.Available at: https://doi.org/10.1152/advan.00078.2010.

Doğan, E., Yılmaz, A. K., Kabadayı, M., \& Mayda, M. H. (2018). Analyze socialization and happiness levels of students in sports sciences faculty and other faculties. Kafkas University Journal of the Institute of Social Sciences, 22(1), 403-411.

Dunn, R. S., \& Dunn, K. J. (1993). Teaching secondary students through their individual learning styles: Practical approaches for grades 7-12: Prentice Hall.

Dunn, R., \& Dunn, K. J. (1992). Teaching elementary students through their individual learning styles: Practical approaches for grades 3-6: Allyn and Bacon.

Fleeming, N. D. (2009). VARK: A guide to learning styles. Retrieved from http://vark-learn.com/the-varkquestionnaire/.

Fleming, N. D. (2001). Teaching and learning styles: VARK strategies, Christchurch, New Zealand.

Gregorc, A. F. (1979). Learning/teaching styles: Their nature and effects. In J. W. Keefe (Ed.) Student learning styles: Diagnosing and prescribing programs (pp. 19-26). Reston, VA: National Association of Secondary School Principals.

Güneş, G., \& Erkan, S. (2017). Analyzing the learning styles of preschool children. Mersin University Journal of the Faculty of Education, 13(1), $13-24$.

Kalkan, M. (2008). Learning preferences and problem-based discussion sessions: A study with Turkish university maritime students. Social Behavior and Personality: An International Journal, 36(10), 1295-1302.Available at: https://doi.org/10.2224/sbp.2008.36.10.1295.

Karataş, H., Sır, N. S., \& Celiköz, N. (2015). An investigation on the learning style preferences of pre-service teachers. Education Sciences, $10(4), 237-252$.

Katsioloudis, P., \& Fantz, T. D. (2012). A comparative analysis of preferred learning and teaching styles for engineering, industrial, and technology education students and faculty. Journal of Technology Education, 23(2), 10-25.Available at: https://doi.org/10.21061/jte.v23i2.a.4.

Kırmacı, Z. İ. K., Nezihe, O., Aktaş, B., Yılmaz, D. A., Karadeniz, P. G., Erel, S., \& Ergen, H. İ. (2019). Determination of learning preferences of SANKO University faculty of medicine and faculty of health sciences students by VARK questionnaire. Journal of Education in Health Sciences, 2(1), 21-28.

Kolb, D. A. (1984). Experience as the source of learning and development. Upper Sadle River: Prentice Hall.

Leite, W. L., Svinicki, M., \& Shi, Y. (2010). Attempted validation of the scores of the VARK: Learning styles inventory with multitraitmultimethod confirmatory factor analysis models. Educational and Psychological Measurement, 70(2), 323-339.Available at: https://doi.org/10.1177/0013164409344507.

Miyake, A., \& Friedman, N. P. (2012). The nature and organization of individual differences in executive functions: Four general conclusions. Current Directions in Psychological Science, 21(1), 8-14.Available at: https://doi.org/10.1177/0963721411429458.

Park, H., Nielsen, W., \& Woodruff, E. (2014). Students' conceptions of the nature of science: Perspectives from Canadian and Korean middle school students. Science \& Education, 23(5), 1169-1196.Available at: https://doi.org/10.1007/s1 1191-013-9613-6.

Powers, C. M. (2016). Music student satisfaction: The relationship between learning style preferences and major satisfaction. Master Thesis.

Riding, R., \& Rayner, S. (2013). Cognitive styles and learning strategies: Understanding style differences in learning and behavior: Routledge.

Türker, U. (2017). Comparison of learning style models and preferences of students in faculty of University. Journal of the Faculty of Education, 13(1), 13-24.

Weng, F., Ho, H.-J., Yang, R.-J., \& Weng, C.-H. (2018). The influence of learning style on learning attitude with multimedia teaching materials. EURASIA Journal of Mathematics, Science and Technology Education, 15(1), em1659.Available at: https://doi.org/10.29333/ejmste/100389.

Wong, R. S., Siow, H. L., Kumarasamy, V., \& Suhaimi, N. S. F. (2017). Interdisciplinary and interinstitutional differences in learning preferences among Malaysian medical and health sciences students. Journal of Advances in Medical Education \& Professionalism, 5(4), $164-168$. 